\title{
LOST IN TRANSLATION: \\ ORALITY AS A TRICKY FILTER OF MEMORY \\ IN ARABO-LATIN PROCESSES OF TRANSFER
}

\author{
Matthias M. Tischler \\ Universitat Autònoma de Barcelona \\ Matthias.Tischler@uab.cat
}

\section{AN UNDER-STUDIED PROBLEM}

What I would like to discuss in this paper is an under-studied methodological problem I came across when I was preparing my research project on transcultural processes of dis/integration of Arabo-Latin texts on Muhammad's life and work, texts belonging to the tradition of Latin universal chronicles between the eighth and the thirteenth centuries: In my opinion, it is necessary to ask ourselves what the interrelationship of written and oral traditions within the field of Arabo-Latin translations looked like, and which specific role was played by orality in this transcultural complex of transfer and transformation.

\section{REFLECTIONS}

In analysing the multiple oral, literate and written processes of transfer and transformation of knowledge about Muhammad's life and work between the Muslim and Christian societies, we are reflecting, on the one hand, on crossing boundaries between different modes of narrations and their cultural patterns, and, on the other hand, we are rethinking the well-established model of interdependent perception and interpretation. One fundamental issue of my research is the analysis of crossing and creating boundaries within the transcultural space of "passages" of oral, literate and written representations of Muhammad's life and

I Marie Curie Senior Fellow-Research Project Muhammad in Latin Christian Contexts. Comparing Modes of Dis/integration of Religious Otherness in Historiographical Traditions, 8th to 13th Centuries within the framework of the ERC/M4HUMAN-Programme of the Gerda Henkel-Stiftung, Düsseldorf. 
work ${ }^{2}$, "passages" which were constituted between the transmission and reception of Muslim and Christian sides. These representations may therefore be called "textual events"3. Whilst considering the multifaceted medieval concept of "text" (Kuchenbuch/Kleine, 2006), we have to assess the relationship between biographical and historiographical writing, stating that each form of representation may occur within the other, and that different textual concepts did exist ${ }^{4}$. However, until now, this crossing of biographical and historiographical writings has not been thoroughly studied, particularly since it is only "Christian hagiography (and historiography) in context" that has been considered in an almost intracultural perspective (Bauer/Herbers, 2000). Furthermore, we see fluid boundaries between Lives and Legends, and both forms of biographical writing are entitled to historical truth and authenticity. Legendary writing within historiography is an item of research as well, yet again this research has been carried out almost from an intracultural point of view (Bietenholz, 1994; Goetz, 1999, p. 147).

When scrutinising these "textual passages", we consider a whole bunch of medial and linguistic, as well as cultural and religious processes of transfer and transformation. Curiously enough, exchanges between oral, literate and written traditions on Muhammad's life and work have not been discussed in the relevant literature on medieval memorys, even though the massive transition from oral to literate representations, especially in historiographical work from our research period, has been broadly studied (Vollrath, I99I —intracultural perspective). Thus, it is expected that behind the variance of recurring components of narratives on Muhammad's life and afterlife there would appear no implicit testimonies of intertextuality, but instead clear hints of foreign and proper orality, which do not mention explicitly the bearers of private information and public opinion.

This evaluation of the state of the art could well be extended to the studies that have been done on three selected Arabo-Latin chronicles (and which are

2 For the difference between literacy ("Verschriftung") and writing ("Verschriftlichung"), cf. Oesterreicher, 1993.

3 Sponsler, 2002, describes "the shifting process of appropriation", but this is unilateral and linear thinking. Burke, 2000 prefers the bilateral term "cultural exchange" ("kultureller Austausch"). I myself suggest the term "passage(s)" (following Walter Benjamin) in Borgolte/Tischler, 20I2, pp. I2-I5. Feuchter e. a., 20II, have underlined the necessity of being attuned to cultural, social and ideological conditions and to their implications for, and in, the representations of cultural transfer.

4 Lifshitz, 1994, wrongly argues that separating historiography and hagiography is not possible until the twelfth century. This statement should be regarded as unfounded, since both modes of inquiring the past belong to different areas of handling knowledge (education, liturgy...).

5 Yates, 1966; Stock, 1983; Goody e. a., 1986; Goody, 1987; Zumthor, 1987; Carruthers, I990 [22008]; Coleman, 1992 [1995]; Geary, I994 [1996]; Richter, 1994a; Richter, 1994b; Wenzel, 1995. Even the Freiburg Collaborative Research Centre 32I "Übergänge und Spannungsfelder zwischen Mündlichkeit und Schriftlichkeit" (1985-1996) did not offer a research project on this central topic. 
subjects of my research project), the Chronica gothorum pseudo-Isidoriana ${ }^{6}$, the Chronica latina regum Castellae ${ }^{7}$ and the Historia Arabum of Rodrigo Jiménez de Rada ${ }^{8}$ : A clear deficit of methodological reflection on transcultural processes of transfer and transformation can be observed, which is consequently followed by a lamentable lack of historical insight into the creation of new Christian narratives of Islam.

Medieval writing on the very early reflected new cultural and religious phenomena (especially in the Byzantine world; cf. Tischler, 20I2) which involved changing the conceptual framework of the historians, was highly influenced by the authors' social, linguistic and cultural proximity to the object of perception and interpretation. Therefore, the written production on cultural and religious alterity depends on the ability to cross at least two barriers: on the one hand, the linguistic and cultural barrier of missing proficiency in Arabic, Syriac and Greek, and on the other hand, the mental and intellectual barrier of ignorance and indifference towards the potential challenges to one's own position by the religious other (Tischler, 2009). Nevertheless, in this model of cultural transfer between relatively distant semiotic systems, the central role of orality or oral communication has not been sufficiently determined. Orality in the processes of transfer and translation, in its proper sense, would mean that we do not consider processes of translation between four eyes (Romano, 197I) or between two hands (d'Alverny, 1989), but processes of convers(at)ion between two mouths and brains. The traces of these processes of oral communication are hidden in the specific forms of narration in our texts.

\section{THREE MODES OF ORALITY}

Different forms of orchestration of oral and written texts may be distinguished here. In the Chronica gothorum pseudo-Isidoriana, our first model, only the final section on the conquest of Spain ${ }^{9}$ is written as a sequence of dialogues: firstly a dialogue at the Visigothic royal court between king Witiza ("Geticus") and an unnamed general ("dux") on the (dishonest) capture of "count" Julian's daughter, then a dialogue between Julian himself and his squire on this fraudulent act, and

6 Chronica gothorum pseudo-Isidoriana.

7 Chronica latina regum Castellae.

8 Rodrigo Jiménez de Rada, Historia Arabum.

9 For the earliest Arabic texts on the conquista of al-Andalus from 7II onwards, and for their often contradictory and lamentably scarce contents, cf. Collins, 1989, p. 4sq.; Molina Martínez, I998; Manzano Moreno, I999. 
finally another dialogue between Julian and Ṭāriq ibn Ziyād on the possible conquest of Spain to revenge this act (ch. 19) (Ed. González Muñoz, 2000, pp. I82I84). Subsequently, after Witiza's death we are presented with a dialogue between his sons and Țāriq ibn Ziyād on how to ensure the victory over king Rodrigo (ch. 20) ${ }^{\mathrm{ro}}$. Finally, there is a conversation between Theudemir and Țāriq ibn Ziyād and between the latter and Julian on the final phase of the conquest (ch. 2I ${ }^{\mathrm{II}}$. This is clearly the Christian-Arabic re-enacting of oral traditions, which are filtered from the Arabic models of anecdotic and dialogic narrations belonging to the so-called "ajbār"-tradition ("traditions on the conquest")

Another mode of orality in written texts is signaled by keywords or "rubrics" that introduce openly oral narratives on contemporary Islam in al-Andalus. In this way, the opinions and news of individuals or whole groups of persons are registered. We can assess this manner of written orality in the Chronica latina regum Castellae, a text which has not yet been studied from this perspective, not even - curiously enough - in its latest critical edition. Rubrics like "dicebatur", "sicut dicebant", "dicebat", "asserebat", "sicut asseritur a multis", "ista didicimus fama referente" or "creditur" convey detailed information on Abd al-Mu'min's (Ibn Tūmart's successor) defeat of the Almoravids ${ }^{13}$, on Ibn Hud's (alias al-Mutawakkil's) rebellion in Murcia and his victory over the Almohads ${ }^{14}$, on Muhammad

Io Ed. González Muñoz, 200o, p. I86. Parallel Arabic text: ar-Rāzī, Crónica del moro Rasis in Crónica general de España de 1344, ed. Catalán/de Andrés, I97I, p. I32sq. (ms. U); cf. Manzano Moreno, I999, pp. 4I3 n. 74 .

II Ed. González Muñoz, 2000, pp. 188-190. Parallel Arabic text: ar-Rāzī, Crónica del moro Rasi, ed. cit., pp. 134-I42 (ms. U). However, Theudemir's surrender of Murcia and Orihuela to Țāriq ibn Ziyād in April 7I3 and its anachronistic positioning between Rodrigo's fall (July 7II) and the occupation of Toledo by Țāriq (October 7II) is paralleled in the Ajbār Măğmüa, most probably from the IIth century, ed./trad. Lafuente y Alcántara, I867 [I984], pp. I2-I5 (Arabic text) and 26-28 (Spanish version).

I2 There has been, for instance, a widespread debate on the oral character of the historiographical compilation Ajbār Mağmü’a; cf. Sánchez Albornoz, 1944; Chalmeta Gendrón, 1973; Molina Martínez, I989; Molina Martínez, I998; Oliver Pérez, 200ıа; Oliver Pérez, 200ıb; Oliver Pérez, 2002.

I3 "Sic et el Mahedi, qui dicebatur Abdelmun de hazedus, qui Moabitas, dominos suos, ad praedicationem Auen Tummert, philosophi de Baldach, regno privavit contra iusticiam sibique gentes et regna subiecit, cum consummavit ista, per Deum zelotem, qui visitavit peccata parentum 'in filios in terciam et quartam generationem' [ $\mathrm{Nm} \mathrm{I4}$, I8; Ex 20, 5], privatus est regno in posteris suis in diebus nostris. 'Sit nomen Domini benedictum' [Ps II2, 2]”, ed. Charlo Brea, 1984, p. 65 11. II-I7.

I4 "Ea vero tempestate surrexit in regno Murcie quidam almogar plebeyus, sicut dicebant, strenuus tum in armis, nomine Abenhut, qui pugnavit contra Murcianos, et eis devictis regem eorum cepit et in vinculis posuit, et civitatem et regnum obtinuit, usus consilio cuiusdam ... Mauri potentis et prudentis, quem postmodum idem Abenhut interfecit. Hodio inexorabili persequebatur Almohades, predicans publice non esse obediendum illis tanquam scismaticis in lege sua, quia non obediunt domino de Baldac, qui est de genere Mahometi. Propter quam causam mezquitas suas dicebat purgandas esse tanquam pollutas Almohadum superstitione. Dicebat eosdem Almohades 
I ibn Nasr's cruel punishment of the brother of the țẩifa king of Baeza ${ }^{\text {I5 }}$ and on Abu Yahya al-Tinmalli's death, full of grief of despair about his son's decapitation $^{16}$; on the other hand "vocatur" or "vocantur" are linked with specific AraboLatin vocabulary ${ }^{17}$. In his report of the reconquest of Úbeda (I233), the author even mentions explicitly Moorish prisoners of that town as his informers ${ }^{18}$, and he relies also on (Christian) eyewitnesses for his description of the marvelous Muslim palace of Córdoba ${ }^{19}$.

Another clearly under-studied aspect in the context of the Arabo-Latin historiography is the persistence of the Arabic tradition; namely, the fact that already in the Arabic models the oral "ajbār"-tradition is an essential foundation of the techniques of compilation in Islamic historiography ${ }^{20}$, so that this very manner of writing history is one of its intrinsic reasons for the variation between narrations of the same historical events. Nevertheless, to our dismay, the memory of the authors of Arabo-Latin processes of transfer was intricately involved in an intensive communication between Arabic-vernacular orality and Latin literacy, which implies the multilingual communication being a tricky filter for creating Latin memory. Orality is therefore not only one of the still under-estimated reasons for the variety of similar (but not identical) traditions produced by processes

oppresores populi et violentos exactores, se vero asserebat liberatorem populi de Handalucia. Sic enim vocatur cismarina terra Maurorum, unde et populi Handaluces vocantur, quos quidam credunt Vandalos esse. Handaluces autem, credentes virtutem divinam in eodem operari - quia mos est populo illi levi persuasione nova sequi - recedentes a domino Almohadum secuti sunt Auehut quasi regem et dominum, qui, ut placeret eis et inimicicias capitales firmaret inter Almohades et Handaluces, atrocissime decrassatus est in eosdem Almohades, viros capitando, iugulando, diversis penis interimendo, mulieribus mamillas amputando, puerorum vitam morte miserabili extinguendo", ibid., p. 75 1. 17 - p. 76 1. 8.

I5 "Quod ut oblatum est ei [sc. "regi Marroquitano"], sicut asseritur a multis, virga, quam tenebat in manu, percussit, verbis contumeliosis usus in dedecus ipsius [sc. "regis Biacie"] et tocius parentele eius. Cui cum respondisset aspere quidam frater regis Biacie, percussus est ab ipso rege Marroquitano cum gladio, et sic orta seditione mul (ti) ex utraque parte cede mutua occubuerunt. Ista didicimus fama referente", ibid., p. 7I 11. I4-20.

I6 "Capta fuit igitur predicta civitas [sc. "Maiorica"] ultima die mensis decembris, anno ab incarnatione domini MCCXXIX. Rex Maiorice post paucos dies mortuus est, decapitato filio eius, quem tenerrime diligebat; unde pre dolore nimio creditur expirasse", ibid., p. 79 l. IO-I4.

I7 Cf. n. I4.

I8 "Sicut referebant aliqui de Mauris ipsis, qui tunc in eadem villa [sc. "Ubeda"] capti fuerunt", ibid., p. 35 1. 7 sq.

I9 "Missa igitur sollempniter celebrata per Osomensem episcopum et benedictione super populum data, dominus rex intravit in palacium nobilissimum, quod reges Maurorum sibi preparaverant, de quo tot et tanta dicuntur ab his qui viderunt, quod a non videntibus incredibilia iudicantur", ibid., p. 100 1. I5-19.

2o Rosenthal, 1968; Chalmeta Gendrón, 1972; Chalmeta Gendrón, I973; Noth/Conrad, 1994 [ ${ }^{2}$ 1997]; Donner, 1998; Robinson, 2003 [2007]. 
of Arabo-Latin transfer, it is also responsible for the reduction of this variety of traditions lost in Arabo-Latin translation. It is exactly this third mode of a more hidden orality that can be found in the Historia Arabum, a text in which Rodrigo's translation team shows this sophisticated scholastic way of homogenising the varying Arabic traditions about the same historical event $s^{21}$. The central challenge in our research is the detection and comprehension of these oral processes, since written records belonging to the vernacular step between the Arabic and Latin versions have only been preserved from the thirteenth century onwards (Menéndez Pidal, I95I, p. 365sq.; d'Alverny, I989, pp. 199-20I).

\section{PERSPECTIVES}

With regard to the historiographical background on the Muslim side, we are now able to understand why, for instance, Wibert of Nogent explicitly mentions orality as the source for his first knowledge of Muhammad and Islam, thus creating a narrative plot of his most reliable referees ${ }^{22}$. And we can also assess better the variance of the seemingly analogue (but never identical) legendary narratives of Muhammad, which apparently emerged in the context of Arabo-vernacularLatin communication situations during their encounters in Northern Spain, and then were inserted into several French chronicles from the late eleventh century onwards, as for instance in those by Hugh of Flavigny ${ }^{23}$ or Hugh of Fleury ${ }^{24}$.

TEXTS

Ajbār Măğmüa, ed./trad. E. Lafuente y Alcántara, Ajbar Machmuâ, Madrid, I867 [repr. Madrid 1984], pp. I-I65 (Arabic text) and I5-I42 (Spanish version).

2I This complex of orality behind Arabo-Latin (historiographical) translations and its transforming effects has not been considered by Maser, 2006; Maser, 2012.

22 Dei gesta per Francos I 3: "Plebeia opinio est quendam fuisse qui, si bene eum exprimo, Mathometus nuncupetur ... Cuius mores vitamque cum nusquam scripta didicerim, quae a quibusdam disertioribus dici vulgo audierim nulli debet esse mirum si dicere velim”, ed. Huygens, 1996, p. 94 11. 244 sq. and $253-255$.

23 Hugh of Flavigny, Chronicon Virdunense seu Flaviniacense, ed. Pertz, I848, p. 323 1. 32-4I; cf. Kedar, I984, p. 2II; Rotter, I994, p. 87sq. with n. II3; Rotter, 2004, p. 332 with n. 239; Tischler, 2008, p. 39.

24 Hugh of Fleury, Historia ecclesiastica (Ist redaction in four books, a. IIO9), ed. Kedar, I984; Historia ecclesiastica (2nd redaction in six books; a. IIIO), ed. Kedar, I984; cf. d'Alverny, 1965, p. 599 with n. 46; Daniel, I975 [ ${ }^{2}$ 1979; ${ }^{2}$ 1986], pp. 235-237; Daniel, I993, p. 31; Noth, I993, p. 379; Rotter, 2004, p. 333sq.; Tischler, 2008, p. 38 with n. 31. 
Chronica gothorum pseudo-Isidoriana, ed. Th. Mommsen, Chronica minora saec. IV. V. VI. VII 2, Berlin I894, pp. 378-388; ed. A. Benito Vidal, Crónica Seudo Isidoriana, València 196I, pp. II-53; ed. F. González Muñoz, La chronica gothorum pseudo-isidoriana (ms. Paris BN 6II3), A Coruña 2000, pp. IIO-I90.

Chronica latina regum Castellae, ed. G. Cirot, "Chronique latine des rois de Castille jusqu'en I236", Bulletin hispanique, I4 (I9I2) pp. I09-II8, 244-274 and 353-374; ibidem, I5 (1913) pp. I8-37, I70-187, 268-283 and 4II-427; ed. M. D. Cabanes Pecourt, Crónica latina de los reyes de Castilla, València, 1964, pp. 15-I24 [Zaragoza ${ }^{3}$ 1985, pp. I5-92]; ed. L. Charlo Brea, Crónica Latina de los reyes de Castilla, Cádiz, 1984 [1999], pp. I-IO2; ed. L. Charlo Brea, Chronica Hispana saeculi XIII, Turnhout, 1997, pp. 35-II8.

Crónica general de España de 1344, ed. D. Catalán y M. S. de Andrés, Edición crítica del texto español de la Crónica de 1344 que ordenó el Conde de Barcelos don Pedro Alfonso, Madrid 197I, pp. I-208.

Hugh of Flavigny, Chronicon Virdunense seu Flaviniacense, ed. G. H. Pertz, MGH Scriptores, 8, Hannover, 1848, pp. 285-502.

Hugh of Fleury, Historia ecclesiastica ( $\mathrm{I}^{\text {st }}$ redaction in four books, a. IIo9), ed. B. Z. Kedar, Crusade and mission, Princeton (NJ.) I984, p. 208 col. a - p. 210 col. a [partial edition]; Historia ecclesiastica $\left(2^{\text {nd }}\right.$ redaction in six books; a. IIIO), ed. ibidem, p. 208 col. b - p. 2 IO col. b [partial edition].

Rodrigo Jiménez de Rada, Historia Arabum, ed. J. Lozano Sánchez, Rodrigo Jiménez de Rada, Historia Arabum, Sevilla, 1974 ['1993], pp. 3-7I; ed. J. Fernández Valverde, Roderici Ximenii de Rada Historiae minores. Dialogus libri vitae, Turnhout, 1999, pp. 87-I49.

Wibert of Nogent, Dei gesta per Francos, ed. R. B. C. Huygens, Guitberti abbatis Sanctae Mariae Novigenti Historia quae inscribitur Dei gesta per Francos quinque accedentibus appendicibus, Turnhout, 1996, pp. 77-352.

STUDIES

d'Alverny, M.-Th., I965: "La connaissance de l'Islam en Occident du IX au milieu $\mathrm{du} \mathrm{XII}^{\mathrm{e}}$ siècle", in L'Occidente e l'Islam nell'alto medioevo, 2, Spoleto, pp. 577602 [repr.: Ch. Burnett (ed.), La connaissance de l'Islam dans l'Occident médiéval, $\left.\mathrm{n}^{\circ} \mathrm{V}\right]$ and 79I-803 (Discussione).

d'Alverny, M.-Th., I989: "Les traductions à deux interprètes, d'arabes en langue vernaculaire et de langue vernaculaire en latin", in G. Contamine (ed.), Traduction et traducteurs au moyen âge, Paris, 1989, pp. 193-206 [repr.: Ch. Burnett (ed.), La transmission des textes philosophiques et scientifiques au moyen 
âge, Aldershot 1994, $\mathrm{n}^{\circ}$ III; F. Micheau (ed.), Les relations des pays d'Islam avec le monde latin du milieu $d u X^{e}$ siècle au milieu du XIII siècle, Paris, 2000, pp. $4 \mathrm{I} 2-43 \mathrm{O}]$.

Bauer/Herbers, 200o: D. R. Bauer/K. Herbers (ed.), Hagiographie im Kontext, Stuttgart.

Bietenholz, P. G., 1994: Historia and fabula, Leiden e. a.

Borgolte/Tischler, 20I2: M. Borgolte/M. M. Tischler (ed.), Transkulturelle Verflechtungen im mittelalterlichen Jahrtausend, Darmstadt.

Burke, P., 2000 [2002]: Kultureller Austausch, Frankfurt am Main.

Carruthers, M. J., 1990 ['2008]: The book of memory, Cambridge e. a.

Chalmeta [Gendrón], P., 1972: "Historiografía medieval hispana. Arabica I", alAndalus, 37, pp. 353-404.

—, I973: "Una historia discontinua e intemporal (jabar)", Hispania, I23, pp. 23-75.

Coleman, J., 1992 [1995]: Ancient and medieval memories, Cambridge e. a.

Collins, R., 1989: The Arab conquest of Spain 710-797, Oxford/Cambridge (Mass.). Daniel, N., I975 [ $\left.{ }^{2} 1979 ;{ }^{2} 1986\right]:$ The Arabs and mediaeval Europe, London/New York.

- I993: Islam and the West, Oxford.

Donner, F. M., 1998: Narratives of Islamic origins, Princeton (NJ.) (etc.).

Feuchter e. a., 20II: J. Feuchter e. a. (ed.), Cultural transfers in dispute, Frankfurt am Main/New York.

Geary, P. J., 1994 [1996]: Phantoms of remembrance, Princeton (NJ.).

Goetz, H.-W., 1999 ['2008]: Geschichtsschreibung und Geschichtsbewußtsein im hohen Mittelalter, Berlin.

Goody, J., 1987: The interface between the written and the oral, Cambridge e. a. (etc.).

Goody e. a., 1986: J. Goody e. a. (ed.), Entstehung und Folgen der Schriftkultur, Frankfurt am Main 1986 (etc.).

Kedar, B. Z., I984: Crusade and mission, Princeton (NJ.).

Kuchenbuch/Kleine 2006: L. Kuchenbuch/U. Kleine (ed.), 'Textus' im Mittelalter, Göttingen.

Lifshitz, F., 1994: "Beyond positivism and genre. 'Hagiographical' texts as historical narrative", Viator, 25, pp. 95-113.

Manzano Moreno, E., I999: "Las fuentes árabes sobre la conquista de al-Andalus. Una nueva interpretación", Hispania, 202, pp. 389-432.

Maser, M., 2006: Die 'Historia Arabum' des Rodrigo Jiménez de Rada, Berlin. 
—_, 2012: "Rodrigo Jiménez de Rada and his 'Historia Arabum'. An extraordinary example of inter-cultural tolerance?", in S. Lambert/H. Nicholson (ed.), Languages of love and hate, Turnhout, pp. 223-238.

Menéndez Pidal, G., 195I: "Cómo trabajaron las escuelas alfonsíes", Nueva revista de filología hispánica, 5, pp. 363-380.

Molina [Martínez], L., 1989: "Los 'Ajbār Maẏmū’a' y la historiografía árabe sobre el período omeya en al-Andalus", al-Qantara, IO, pp. 513-542.

—, 1998: "Un relato de la conquista de al-Andalus", al-Qantara, I9, pp. 39-65.

Noth, A., I993: "Muhammed 3. The Prophet's image in Europe and the West. A. The image in the Latin middle ages", in The Encyclopaedia of Islam 7, Leiden/ New York, pp. 377-38I.

Noth, A./Conrad, L. I., I994 ['²1997]: The early Arabic historical tradition, Princeton (NJ.).

Oesterreicher, W., 1993: “Verschriftung' und 'Verschriftlichung' im Kontext medialer und konzeptioneller Schriftlichkeit", in U. Schaefer (ed.), Schriftlichkeit im frühen Mittelalter, Tübingen, pp. 267-292.

Oliver Pérez, D., 20ora: "El Ajbar Maymua. Una obra polémica", Qurtuba, 6, pp. 77-108.

— , 20orb: "Los autores del Ajbar Maymu'a. ¿Los Tammam b. 'Alqama?", Anaquel de estudios árabes, $\mathrm{II}-\mathrm{I} 2$, pp. 513-554.

Oliver Pérez, D., 2002: "De vuelta sobre el Ajbar Maymu'a. La historia de la invasión y de los valíes", Anaquel de estudios árabes I3, pp. I3I-I5O.

Richter, M., 1994a: The formation of the medieval West, Dublin.

- I994b: The oral tradition in the early middle ages, Turnhout.

Robinson, C. F., 2003 [2007]: Islamic historiography, Cambridge.

Romano, D., 1971: "Le opere scientifiche di Alfonso X e l'intervento degli ebrei", in Oriente e occidente nel medioevo, Roma, pp. 677-7II and 726-729 (Discussione).

Rosenthal, F., 1968: A history of Muslim historiography, Leiden.

Rotter, E., 1994: "Embricho von Mainz und das Mohammed-Bild seiner Zeit", in F. Staab (ed.), Auslandsbeziehungen unter den salischen Kaisern, Speyer, pp. 69-I22.

Rotter, E., 2004: "Mohammed in Bamberg. Die Wahrnehmung der muslimischen Welt im deutschen Reich des II. Jahrhunderts", in A. Hubel/B. Schneidmüller (ed.), Aufbruch ins zweite Jahrtausend, Ostfildern, pp. 283-344.

Sánchez Albornoz, C., 1944: El 'Ajbār maẏmü'a', Buenos Aires.

Sponsler, C., 2002: "In transit. Theorizing cultural appropriation in medieval Europe", Journal of Medieval and Early Modern Studies, 32, pp. 17-39.

Stock, B., I983: The implications of literacy, Princeton (NJ.). 
Tischler, M. M., 2008: "Orte des Unheiligen. Versuch einer Topographie der dominikanischen Mohammed-Biographik des I3. Jahrhunderts zwischen Textüberlieferung und Missionspraxis", Archa Verbi, 5, pp. 32-63.

__, 2009: "Grenzen und Grenzüberschreitung in der christlich-muslimischen Begegnung. Bemerkungen zum Stellenwert der Arabischkenntnisse in der abendländischen Missionsgeschichte”, Zeitschrift für Missionswissenschaft und Religionswissenschaft, 93, pp. 58-75.

— - 20I2: "Eine fast vergessene Gedächtnisspur. Der byzantinisch-lateinische Wissenstransfer zum Islam (8.-I3. Jahrhundert)", in A. Speer/Ph. Steinkrüger (ed.), Knotenpunkt Byzanz, Berlin/Boston, pp. 167-195.

Vollrath, H.: "Oral modes of perception in eleventh-century chronicles", in A. N. Doane/C. Braun Pasternack (ed.), Vox intexta, Madison (Wisc.) I99I, pp. IO2-III.

Wenzel, H., 1995: Hören und Sehen, Schrift und Bild, München.

Yates, F. A., I966 [1972]: The art of memory, London.

Zumthor, P., 1987: La lettre et la voix, Paris. 